\title{
Radiocarbon
}

1974

\section{CAIRO NATURAL RADIOCARBON MEASUREMENTS I}

\author{
SHAWKI M NAKHLA and FERIAL M MOHAMMED
}

Carbon-14 Dating Laboratory, Center of Research and Conservation of Antiquities, Organisation of Egyptian Antiquities, Cairo

\author{
INTRODUCTION
}

The Organisation of Egyptian Antiquities believes that Egypt should play an important role in current international research in the field of radiocarbon dating of archaeologic samples. Thus, such a labora. tory was established within the Center of Research and Conservation of Antiquities, CRGA, Cairo.

Electronics and much of the glass equipment were contributed by the French government for applied archaeologic research in Egypt.

The laboratory began operating in 1971 using the carbon dioxide proportional counter technique. Our proportional gas counter was made at the Centre des Faibles Radioactivités, France, with an effective volume of $1.2 \mathrm{~L}$. The counter is surrounded by 40 Geiger counters $\mathrm{L}$ cd-8 in 2 alternative layers and arranged in anticoincidence. The counters are within an iron shield $30 \mathrm{~cm}$ thick. The iron used was completely free from radioactive contamination. The pulses are counted by a transistor apparatus made by Intertechnique, France. The background is $3.1 \mathrm{cpm}$ and the counting rate of oxalic acid standard from NBS is $10.12 \mathrm{cpm}$ at normal counting pressures. The sample is introduced into the counter as purified carbon dioxide at a pressure of 1 atmosphere.

The sample, after being cleaned mechanically, is generally treated with hot $2 \% \mathrm{NaOH}$, followed by hot $10 \% \mathrm{HCl}$ and then washed with hot, distilled water several times until the resulting solution is neutral to an acid indicator, then dried at $80^{\circ} \mathrm{C}$. The sample is then burnt in a stream of oxygen and the $\mathrm{CO}_{2}$ formed is purified by passing it over hot $\mathrm{CuO}\left(600^{\circ} \mathrm{C}\right), 0.1 \mathrm{~N} \mathrm{AgNO}_{3}$ and $\mathrm{H}_{2} \mathrm{SO}_{4} \cdot \mathrm{CrO}_{3}$ solutions successively to remove halides, nitrogen, and sulphur oxides. The $\mathrm{CO}_{2}$ is generally stored for 3 weeks to allow for complete decay of radon. It is then submitted to a process of fractional distillation using liquid nitrogen and a cooling mixture at $-80^{\circ} \mathrm{C}$. The gas is then trapped over alumina to eliminate electronegative impurities, dried by passing it over $\mathrm{P}_{2} \mathrm{O}_{5}$, and the proportional counter is filled at 1 atmosphere. The sample is generally counted for 2 successive nights. All dates are calculated both in years before 1950 and in the $\mathrm{AD} / \mathrm{BC}$ scale. The applied ${ }^{14} \mathrm{C}$ half-life is $5570 \mathrm{yr}$. The NBS recent standard is $95 \%$ of the ${ }^{14} \mathrm{C}$ activity in the oxalic acid. 


\section{ACKNOWLEDGMENTS}

The authors wish to thank Gamal Moukhtar, Chairman, Organisation of Egyptian Antiquities, Zaky Iskander, Dir Gen, for the help offered during the construction of the laboratory. They wish also to express their deep gratitude to Jacques Labeyrie, chief, Centre des Faibles Radioactivités, France, and Georgette Delibrias, chief, Gif Radiocarbon Dating Laboratory for advice and help in establishing the laboratory.

\section{Karnak series}

\section{SAMPLE DESCRIPTIONS}

The Karnak temples at Thebes $\left(25^{\circ} 43^{\prime} \mathrm{N}, 32^{\circ} 39^{\prime} \mathrm{E}\right)$, the most famous temples in Ancient Egypt, were built over a long period of time. The oldest part was constructed ca $2000 \mathrm{BC}$ and the temples continued in use until early Christian times.

Varied samples from different dynasties were coll 1971 by one of us (S Nakhla) with the staff of the Franco-Egyptian Center for the Study and Restoration of the Karnak temples. Five soil samples were taken from different depths in front of the $\mathrm{W}$ wing of the 1st pylon, ca $60 \mathrm{~m}$ from the Nile $\mathbf{R}$. The samples described here are the lst part of this group.

\section{CRCA-4.}

Carbonized wood from a piece of furniture found during the FrancoEgyptian excavations near the $\mathrm{W}$ side of the 1st pylon built by Nectanebo I of the XXXth Dynasty (378 to 360 вс).

\section{CRCA-6.}

$2943 \pm 120$

A wooden dove-tail wedge found between blocks of $\mathbf{E}$ part of the Sanctuary of the temple of Harpré. The temple is in $\mathrm{N}$ part of the Karnak temples and supposedly was built during the XXIst dynasty, 1080 to 950 BC (Jacquet, pers commun).

\section{CRCA-5.}

$2162 \pm 100$

A wooden dove-tail wedge found between sandstone blocks of IXth pylon, built during the reign of Horemheb, the last king of the XIXth dynasty, 1340 to 1320 BC. Comment: date indicates that the pylon may have been reconstructed or restored during the Greaco-Roman period.

\section{CRCA-8. Soil 8 to $18 \mathrm{~cm}$}

$\delta^{14} \mathrm{C}=12 \%$

Organic fraction from soil $8 \mathrm{~cm}$ from surface. Land was cultivated a few years ago and is now covered with wild grasses. Recent vegetation is responsible for presence of atomic bomb effect in this layer.

CRCA-33. 
CRCA-9. Soil 90 to $110 \mathrm{~cm}$

$1220 \pm 120$

Organic fraction from a dark continuous archaeologic layer that probably was inhabited before as it contains traces of bricks, pottery, glass, and other artifacts.

CRCA-10. Soil 170 to $190 \mathrm{~cm}$

$1582 \pm 120$

Organic fraction from a dark mud layer. AD 368

CRCA-11. Soil 270 to $290 \mathrm{~cm}$

$1440 \pm 120$

Organic fraction from a brownish mud layer. AD 510

\section{CRCA-12. Soil 360 to $380 \mathrm{~cm}$}

$1504 \pm 120$ AD 446

Organic fraction from a yellowish sandy layer. Comment: port of Karnak was reconstructed during Roman occupation, which may explain relatively young ages obtained for layers 170 to $380 \mathrm{~cm}$. Presence of artifacts in layer 90 to $110 \mathrm{~cm}$ indicates that level may have been inhabited some 1220 yr ago. Date corresponds to Christian epoch in Egypt and the beginning of Arabic period.

\section{CRCA-32.}

$3433 \pm 100$

Pieces of cedrus libani from tomb of Tutankhamon (18th dynasty), valley of the Kings $\left(25^{\circ} 40^{\prime} \mathrm{N}, 32^{\circ} 30^{\prime} \mathrm{E}\right)$ Thebes, Egypt. Coll 1971 by SM Nakhla and M Saleh from excavation colln at Qurna.

\section{CRCA-65.}

$3284 \pm 100$

Pieces of cedrus libani from funerary furniture of Tutankhamon, valley of the Kings, Thebes. Colln of A Lucas, Center of Research and Conservation of Antiquities, Cairo. Comment: tomb of Tutankhamon was discovered by Howard Carter in 1922 (Carter, 1933). Historical date of reign of Tutankhamon is 1352 to $1343 \mathrm{BC}$.

\section{CRCA-44.}

$$
\begin{aligned}
& 3274 \pm 120 \\
& 1324 \mathrm{BC}
\end{aligned}
$$

Wood from Serdab behind burial chamber of Seti I (19th dynasty), valley of the Kings $\left(25^{\circ} 40^{\prime} \mathrm{N}, 32^{\circ} 30^{\prime} \mathrm{E}\right.$ ), Thebes. Coll 1971 and subm by $\mathrm{Z}$ Iskander. Comment: Seti I was the son of Ramsis I, the founder of the 19th dynasty. He reigned from 1327 to 1306 B.c.

\section{CRCA-38.}

$3886 \pm 150$

$1936 \mathrm{BC}$

Trunk found embedded in soil during German excavations at Assasif $\left(52^{\circ} 40^{\prime} \mathrm{N}, 32^{\circ} 30^{\prime} \mathrm{E}\right)$, Thebes. Coll 1971 and subm by A Arnolds. Comment: trunk is dated archaeologically at time of Mentuhotep II from XIth dynasty (2050 to $2010 \mathrm{BC}$ ). 


\section{CRCA-33.}

Reeds found as sheets between mudstraw bricks of arcades facing tomb of Mentu-em-hat (26th dynasty) Assasif $\left(25^{\circ} 40^{\prime} \mathrm{N}, 32^{\circ} 30^{\prime} \mathrm{E}\right)$, Thebes. Commen:: date indicates reeds are much older than tomb of Mentu-em-hat, dated archaeologically at 600 вс. Thus arcades may have been built or reconstructed during the 18 th dynasty.

\section{CRCA-22.}

$4387 \pm 150$

2437 BC

Reeds from tomb of Khenamon, Assasif $\left(25^{\circ} 40^{\prime} \mathrm{N}, 32^{\circ} 30^{\prime} \mathrm{E}\right)$, Thebes. Coll 1971 and subm by M Saleh. Comment: tomb of Khenamon was discovered in $1961 \mathrm{br}$ M Saleh and is dated from Old Kingdom (3200 to 2280 вС).

\section{CRCA-35.}

$2370 \pm 120$

Plant debris fsom one of tombs excavated by Antiquities Dept Egypt in region of Abo-Bello (30 26 $6^{\prime}$ N, 30 $40^{\circ} \mathrm{E}$ ), Egypt. Coll 1971 and subm by $\mathrm{S}$ El Bakry. Comment: region of Abo-Bello includes tombs from Graeco-Roman period and early Christian times.

\section{CRCA-37.}

$$
1890 \pm 120
$$

Human bones from one of tombs discovered during excavation by Ministry of Industry in 1971 at Helwan dist. Coll 1971 and subm by A Nassef. Comment: tombs are part of ancient public cemetery and are dated archaeologically from Roman and early Christian times (M Basta, pers commun).

\section{CRCA-46.}

Carbonized wood from $W$ furnaces on road of ram-headed sphinxes leading from Luxor temple to Karnak temples $\left(25^{\circ} 43^{\prime} \mathrm{N}, 32^{\circ} 39^{\prime} \mathrm{E}\right)$, Thebes. Coll 1971 and subm by S El Bakry.

\section{CRCA-36.}

$10,580 \pm 200$

8630 BC

Carbonized wood, 55 to $60 \mathrm{~m}$ from surface in region of Tala Betous $\left(30^{\circ} 40^{\prime} \mathrm{N}, 30^{\circ} 5^{\prime \prime} 7^{\prime} \mathrm{E}\right)$, Menoufiia, Egypt, during excavation by Dept Chem Egypt for geochemical study of Nile Delta. Coll 1971 and subm by M Abd El Aziz.

\section{CRCA-57.}

$2254 \pm 100$

Carbonized wcod found during Polish excavations, $10 \mathrm{~m}$ from surface at Kom El Dikka $\left(31^{\circ} 40^{\prime} \mathrm{N}, 2^{\circ} 55^{\prime} \mathrm{E}\right)$ Alexandria, Egypt. Region of Kom El Dikka is archaeologically dated from Graeco-Roman times and includes the famous Roman theater. 
CRCA-43.

$4750 \pm 200$

$2800 \mathrm{BC}$

Carbonized wood from one of furnaces in ancient village discovered by Univ Cairo in region of pyramids $\left(29^{\circ} 58^{\prime} \mathrm{N}, 31^{\circ} 7^{\prime} \mathrm{E}\right)$ Giza, Egypt. Coll 1971 and subm by A Saleh. Comment: pyramids belong to Kings from IVth dynasty (2680 to $2563 \mathrm{BC}$ ).

\section{REFERENCES}

Carter, Howard, 1923, The Tomb of Tut-Ankh-Amen: London, Cassell and Co, Ltd, r $1-3$.

Delibrias, G and Nakhla, S M, 1972, Study of some podzol-levels from France by C-14 dating of humic matter: Internatl Radiocarbon Dating Conf, Wellington, New Zealand.

Labeyrie, J, 1955, La mesure d'âge des fossiles par la méthode du carbone radioactif $\left({ }^{14} \mathrm{C}\right)$ naturel: L'onde électrique, v 35, p 1084

Libby, W F, 1955, Radiocarbon dating, 2nd ed: Chicago, Univ Chicago Press, ix, 175 p.

Nakhla, S M and Delibrias, G, 1967, Utilisation du carbone-14 d'origine thermonucléaire pour l'ćtude de la dynamique du carbone dans le sol: IAEA Conf Radioactive dating and methods of low level counting Proc, Monaco, p 169.

Perquis, M T, Delibrias, G, and David B, 1956, Mesure par comptage proportionnel cn phase gaseuse de substance a très faible activité spécifique dûe au carbone-14, application aux "datage": DIST 11 (1956, CEN Saclay).

Perrin, R M S, Willis, E H, and Hodge, C A H 1964, Dating of humus podzols by residual radiocarbon activity: Nature, v 202, p 165-166. 